\title{
Elicitors and Plant Defence
}

\author{
Moreno-Pérez A ${ }^{1}$, Martínez-Ferri E ${ }^{2}$, Pliego-Alfaro $\mathrm{F}^{3}$ and Pliego $\mathrm{C}^{1 *}$ \\ ${ }^{1}$ Department of Genomics and Biotechnology, Fruticultura Subtropical y Mediterránea (IFAPA) Unidad Asociada de I+D+i al CSIC, Málaga, Spain \\ ${ }^{2}$ Department of Crop Ecophysiology, Fruticultura Subtropical y Mediterránea (IFAPA) Unidad Asociada de I+D+i al CSIC, Málaga, Spain \\ ${ }^{3}$ Department of Botany and Plant Physiology, IHSM UMA-CSIC La Mayora, Málaga, Spain
}

Submission: May 21, 2020; Published: June 15, 2020

"Corresponding author: Pliego C, Department of Genomics and Biotechnology, Fruticultura Subtropical y Mediterránea (IFAPA) Unidad Asociada de I+D+i al CSIC, Málaga, Spain

\begin{abstract}
Pest and disease control in agricultural crops include the use of chemicals which could be hazardous for people and environment. The obtainment of resistant genotypes as well as development of new strategies more environmentally friendly, seems to be of high priority in a sustainable agriculture. The use of elicitors to induce a faster and stronger defence response in plants seems to be a promising alternative. In this review, the different type of elicitors according to nature (physical or chemical), origin (biotic or abiotic) or structure (complex or well defined) are indicated. An insight into the complexity of the action mechanism, from perception at plasma membrane to the appearance of defence related products (phytoalexins and PR proteins, among others), as well as the evaluation of factors determining the success of elicitation are included. Finally, the priming process and its epigenetic basis, cross-factor priming and its possible use to improve disease management on commercial fruit orchards and the possibilities that transgenerational priming offers as a breeder's tool, are discussed.

Keywords: Disease control; Improved plant response, Stress exposure, Priming,

Abbreviations: AVR: Avirulent Gen; BABA: $\beta$-Aminobutyric Acid; CGMP: Cyclic Guanosine Mono Phosphate; cADPR: Cyclic Adenosine DiphosphateRibose; MeJA: Methyl Jasmonate; NAC domain: N-terminal 160 Aminoacids domain; NPR1: Non-Expressor of Pathogenesis-Related gene 1; PR: Pathogenesis Related gene; PR1: Pathogenesis Related 1 gene; qRT-PCR: quantitative Reverse Transcription Polymerase Chain Reaction; R: Resistance gene; RD1 \& RD2: Rice Drought responsive genes 1 and 2; SA: Salicylic Acid; SAR: Systemic Acquired Resistance; StWRKY1: Solanum tuberosum WRKY 1; UV-B: Ultraviolet-B radiation
\end{abstract}

\section{Introduction}

Plants are continually exposed to different stress factors which could be either biotic (bacteria, fungi, viruses, insects, herbivores and oomycetes) [1,2] or abiotic (heavy metals, salinity, ozone, UV-B radiation, extreme temperature, excess or lack of nutrients, drought) in nature [3]. These factors cause general damage in plants and economically important losses in cultivated land [4]. To counteract these problems, several approaches are being undertaken including the use of physical (solarization, culture rotation) chemical (pesticides or fungicides) or biological control (antagonist microorganisms) methods as well as development of resistant genotypes [5]. Moreover, damage caused by the use of previous approaches on people, plants, animals and environment is of great concern to general public; ca. use of pesticides is linked to residues accumulation in water and soil, harmful to human health and environment while use of physical methods such as tillage is linked to erosion problems [6]. In this scenario, there exists an increasing demand for alternative approaches, more environmentally friendly, and the use of elicitors appears as an interesting biological alternative.

\section{Elicitors}

Elicitors are either molecules or compounds which upon application to the plant induce important physiological changes; ca. similar mechanisms to those appearing in plant responses to pathogens or environmental stress are initiated, affecting plant metabolism and enhancing the biosynthesis of secondary metabolites [7,8]. According to Zheng [6] use of elicitors has several advantages over other approaches, e.g., they are non-toxic and environmentally friendly, and more important, small amounts are enough to provide the plants with long time protection to a wide range of pathogens.

\section{Classification}

There are different ways to classify elicitors. In accordance to Radman [9] they could be divided into physical or chemical, biotic 
or abiotic and complex or well defined, considering nature, origin or molecular structure. Vasconsuelo \& Boland [1] when studying elicitation to increase production of secondary metabolites under in vitro conditions and Baenas [7], in their review of elicitation as tool to increase content of bioactive compounds, emphasize the importance of origin and classify elicitors into biotic (exogenous, those of biological origin appearing as result of fungal, bacterial or virus infections, or endogenous, produced by the plant as result of pathogen attack) or abiotic (physical or chemical) and plant hormones. Another way of classification would be considering the relation between plant and elicitor, considering general elicitors as those inducing unspecific defence mechanisms in different crops and specific elicitors only affecting a determinate host $[1,7]$. An overview of elicitors classification can be found in (Figure 1).

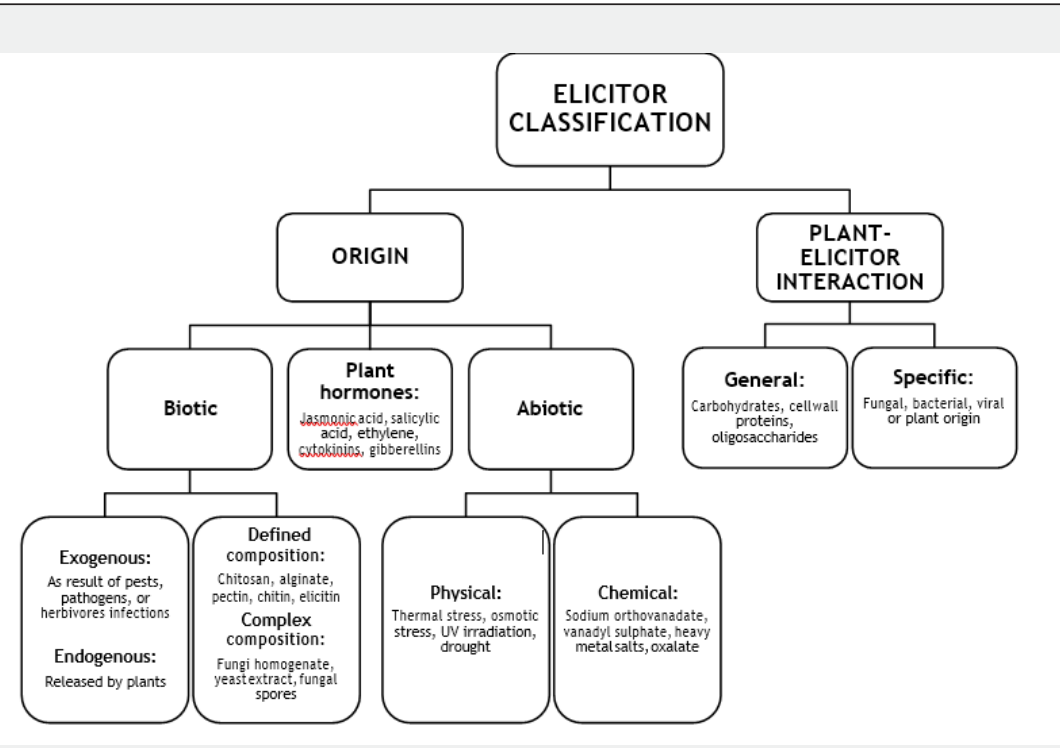

Figure 1: Elicitor classification in accordance to origin or the interaction plant-elicitor. Adapted from Vasconsuelo \& Boland [1], Baenas [7] and Radman [9].

\section{Mechanisms of action}

Generally, the first step in elicitor signaling would be its detection by receptors located in plasma membrane: moreover, since elicitors can have very different chemical structures, they will show rather different effects depending upon the species in question [1]. Various receptors for elicitors with different structures have been identified so far; it appears that the interaction between plant resistance genes products acting as receptors for AVR (pathogen avirulent gen) merits special consideration to understand response to elicitors [10]. At the same time, a given elicitor could induce responses in different plants, indicating that common receptors should exist in different systems [11]. Signal transduction does not follow a simple model but rather a heavily branched one, where different secondary messengers (free calcium, active oxygen species, cytosolic $\mathrm{pH}$, nitrogen oxide, cGMP and cADPR, among others) interact in each branch. Appearance of profound changes in pentose phosphate pathway and Krebs cycle are indications of serious effects on cell behavior; ca. triggering defence response is often associated with induction of abiotic stress in the cell $[10,11]$. In any case, activation of signal transduction pathways results in production of phytoalexins, strengthening of cell wall through callose deposition as well as accumulation of pathogenesis related proteins (PR) $[2,5,8]$, with specificity of the response relying on the role played by different secondary messengers and the appearance of targeted proteins at specific times and places [10]. Complexity of the integrated response, cumulative data from the different signaling pathways and their occurrence in different plant species, requires use of computer analysis to integrate at cell level the role played by specific components $[10,12]$.

Although elicitors were initially used to activate plant defence mechanisms, it was observed that, in many cases, elicitation was linked to accumulation of secondary metabolites of great interest in pharmaceutical, cosmetic and agro-food industries [13]. In a recent review, Giri \& Zaheer [14] reported that metabolite accumulation could increase in the range 1-2230-fold following elicitor application to in vitro cultures (callus, cell suspensions, roots, shoots). Moreover, in postharvest treatments, elicitors can increase nutritional value in grapes (enhanced antioxidant properties) [15] or shelf life, in horticultural crops [16,17] as well as in ginseng roots [18].

\section{Factors affecting the elicitation process}

Plant-elicitor interaction is a rather complex phenomenon and its success will depend upon numerous factors $[1,13]$. Initially, elicitor specificity merits to be considered, ca. a plant can show positive responses to different elicitors while a given elicitor could induce defence reactions in different plants. Elicitor concentration 
is another important factor to be taken into account; ca. Jesús [19] found that foliar treatments with Salicylic Acid (SA) (0,75-5 mM) increased drought tolerance in Eucalyptus globulus and this effect was dependent on the dosage applied, highest dosage being more effective. Similar effects had previously been observed by Singh \& Usha [20] in wheat seedlings, where decreased transpiration rate and improved photosynthesis were linked to improved behaviour under water stress conditions. A decrease in transpiration rate was also observed following applications of chitosan to basil plants, improving behaviour under drought stress [21]. Time and frequency of application are also key factors to be considered when optimizing elicitor effects in plant response, with application frequency being linked to persistence of the response. Culture type and growing conditions will determine the most appropriate application method. In accordance to Rohwer \& Erwin [22], Methyl Jasmonate (MeJA) could be applied as a gas [23], mixed with lanolin paste [24], in liquid form [25] or, most commonly, as spray with a surfactant agent [26].

\section{Priming}

Following elicitation or plant exposure to a stress situation induces physiological changes in such a way, that plant will show a faster and stronger response when exposed to subsequent stress conditions (priming). Stress exposure or elicitor treatments generally induce modifications in histone proteins at defence related genes, suggesting an epigenetic base of the priming mechanism $[27,28]$. Along this line, investigations being carried out by our group within the pathosystem Persea americana (avocado) and the soilborne pathogen Rosellinia necatrix (causal agent of White Root Rot), have shown that application of either SA or MeJA ( $5 \mathrm{mM})$ to plants prior to fungal inoculation induced a 15 day delay, in plant death. Moreover, qRT-PCR quantification of the defence protease inhibitor gene, showed a 4- and 5-fold increases following elicitation with salicylate and jasmonate, respectively, in root samples after 12 hours (Clara Pliego, IFAPA-Málaga, unpublished results, May, 18, 2020). Previous investigations, also in avocado plants, had shown that exposure to mild water stress improved plant response to White Root Rot (cross-factor priming) [29]; the improved performance of avocado plants was linked to a general increased expression of plant defence genes, in particular those coding for NPR1 protein and NAC domain containing protein 72 , leading these authors to conclude that adequate irrigation management could be an useful strategy to control fungal infections in commercial avocado orchards. In rice, Samota [30] observed that seed elicitation with methyl jasmone induced changes in expression of drought responsive genes RD1 and RD2 and plants derived from the elicited seeds would respond better to water stress than those from control seeds. It has also been shown that stress-induced epigenetic changes occurring during the seed formation process could be transmitted to the progeny (transgenerational stress memory) [27, 31, 32]. Along this line, Slaughter [33] observed that seed progeny of Arabidopsis plants, treated with an avirulent strain of
Pseudomonas syringae pv tomato, showed an enhanced resistance to a virulent strain while Luna [34] found a higher expression of SAR genes in Arabidopsis plants exposed to a virulent strain of the same bacteria, Pseudomonas syringae pv tomato DC3000. Seed progeny showed enhanced tolerance to this bacterial strain and to the hemi biotrophic fungus Hyaloperonospora arabidopsidis while it was more susceptible to the necrotrophic pathogen Alternaria brassicicola In the woody perennial Quercus ilex, seedlings derived from acorns collected from trees infected with Phytophthora cinnamomi under field conditions, showed a better response following artificial inoculation with the oomycete [35]. The tuber or seed progeny from $\beta$-Amino Butyric acid (BABA) elicited potato, showed an enhanced resistance to Phytophthora infestans, linked to methylation changes in the R3a resistance gene as well as other SA dependent genes (NPR1, StWRKY1, PR1) [36]. Similar results were obtained by Ramirez-Carrasco [37], also with the BABA elicitor in Phaseolus vulgaris, ca. seed progeny showed enhanced resistance to Pseudomonas syringae pv. phaseolicola. In this case, increased resistance was linked to an enhanced expression of Phaseolus vulgaris PR1, a highly responsive gen to elicitation. These results led Ramirez-Carrasco [37] to recommend elicitation as a tool to be used for breeders by priming plants in the field and selecting induced heritable states in the progeny.

\section{Conclusions}

Use of elicitors have become an important tool to gain knowledge on defence responses in plants; at the same time, they can be used to improve plant response to stress situations in an environmentally friendly way. Moreover, the occurrence of crossfactor priming offers an interesting alternative to manage pest and diseases in commercial plantings while transgenerational priming appears as an important tool to be used by plant breeders for increasing resistance to biotic and abiotic factors through selection of induced heritable states in the progeny of primed plants.

\section{Acknowledgments}

C Pliego is currently supported by an INIA-CCAA contract, cofinanced by INIA 16 (20\%) and FEDER (80\%). A. Moreno-Pérez is financed by a PhD FPI-INIA (RTA2017-00040-00) contract cofinanced by FSE. Part of the results included in this review have been carried out in the frame of projects RTA2017-00040-00 and AVA2019.008.

\section{References}

1. Vasconsuelo A, Boland R (2007) Molecular aspects of the early stages of elicitation of secondary metabolites in plants. Plant Science 172(5): 861-875.

2. Ali S, Ganai BA, Kamili AN, Bhat AA, Mir ZA, et al. (2018) Pathogenesis-related proteins and peptides as promising tools for engineering plants with multiple stress tolerance. Microbiological Research 212: 29-37.

3. Kahn MIR, Fatma M, Per TS, Anjum NA, Khan NA (2015) Salicylic acid-induced abiotic stress tolerance and underlying mechanisms in plants. Frontiers in Plant Science 6: 462. 
4. Cramer GR, Urano K, Delrot S, Pezzotti M, Shinozaki K (2011) Effects of abiotic stress on plants: a systems biology perspective. BMC Plant Biology 11(1): 163.

5. Thakur M, Sohal BS (2013) Role of elicitors in inducing resistance in plants against pathogen infection: a review. ISRN Biochemistry 2013 762412

6. Zheng F, Chen L, Zhang P, Zhou J, Lu X, et al. (2020) Carbohydrate polymers exhibit great potential as effective elicitors in organic agriculture: A review. Carbohydrate Polymers 230 (15): 115637.

7. Baenas N, García-Viguera C, Moreno DA (2014) Elicitation: a tool for enriching the bioactive composition of foods. Molecules 19(9): 1354113563.

8. Jamiołkowska A (2020) Natural compounds as elicitors of plant resistance against diseases and new biocontrol strategies. Agronomy 10(2): 173.

9. Radman R, Saez T, Bucke C, Keshavarz T (2003) Elicitation of plants and microbial cell systems. Biotechnology and Applied Biochemistry 37(1): 91-102.

10. Garcia-Brugger A, Lamotte O, Vandelle E, Bourque S, Lecourieux D, et al. (2006) Early signaling events induced by elicitors of plant defenses. Molecular Plant-Microbe Interactions 19(7): 711-724.

11. Ramirez-Estrada K, Vidal-Limon H, Hidalgo D, Moyano E, Golenioswki M, et al. (2016) Elicitation, an effective strategy for the biotechnological production of bioactive high-added value compounds in plant cell factories. Molecules 21(2):182.

12. Treviño Santa Cruz MB, Genoud D, Métraux JP, Genoud T (2005) Update in bioinformatics: Toward a digital database of plant cell signaling networks: advantages, limitations and predictive aspects of the digital model. Phytochemistry 66(3): 267-276.

13. Narayani M, Srivastava S (2017) Elicitation: a stimulation of stress in in vitro plant cell/tissue cultures for enhancement of secondary metabolite production. Phytochemistry Reviews 16(6): 1227-1252.

14. Giri CC, Zaheer M (2016) Chemical elicitors versus secondary metabolite production in vitro using plant cell, tissue and organ cultures: recent trends and a sky eye view appraisal. Plant Cell Tissue and Organ Culture 126(1): 1-18

15. Crupi P, Pichierri A, Milella RA, Perniola R, Antonacci D (2014) Role of the physical elicitors in enhancing postharvest antioxidant capacity of table grape cv redglobe (Vitis vinifera L.). Journal of Food Research 3(2): 61.

16. Terry LA, Joyce DC (2004) Elicitors of induced disease resistance in postharvest horticultural crops: a brief review. Postharvest Biology and Technology 32(1): 1-13.

17. Feliziani E, Landi L, Romanazzi G (2015) Preharvest treatments with chitosan and other alternatives to conventional fungicides to contro postharvest decay of strawberry. Carbohydrate Polymers 132: 111117

18. Liu Z, Xia J, Wang CZ, Zhang JQ Ruan CC, et al. (2016) Remarkable impact of acidic ginsenosides and organic acids on ginsenoside transformation from fresh ginseng to red ginseng. Journal of Agricultural and Food Chemistry 64(26): 5389-5399.

19. Jesus C, Meijón M, Monteiro P, Correia B, Amaral J, et al. (2015) Salicylic acid application modulates physiological and hormonal changes in Eucalyptus globulus under water deficit. Environmental and Experimental Botany 118: 56-66.
20. Singh B, Usha K (2003) Salicylic acid induced physiological and biochemical changes in wheat seedlings under water stress. Plant Growth Regulation 39(2): 137-141.

21. Malekpoor F, Pirbalouti AG, Salimi A (2016) Effect of foliar application of chitosan on morphological and physiological characteristics of basil under reduced irrigation. Research on Crops 17(2): 354-359.

22. Rohwer CL, Erwin JE (2008) Horticultural applications of jasmonates. The Journal of Horticultural Science and Biotechnology 83(3): 283304.

23. Farmer EE, Ryan CA (1990) Interplant communication: airborne methyl jasmonate induces synthesis of proteinase inhibitors in plant leaves. Proceedings of the National Academy of Sciences 87(19): 7713-7716.

24. Saniewski M, Miyamoto K, Ueda J (1998) Methyl jasmonate induces gums and stimulates anthocyanin accumulation in peach shoots. Journal of Plant Growth Regulation 17(3): 121-124

25. Baldwin IT (1996) Methyl jasmonate-induced nicotine production in Nicotiana attenuata: inducing defenses in the field without wounding.. Entomologia Experimentalis et Applicata 80(1): 213-220.

26. Janoudi A, Flore JA (2003) Effects of multiple applications of methyl jasmonate on fruit ripening, leaf gas exchange and vegetative growth in fruit trees. The Journal of Horticultural Science and Biotechnology 78(6): 793-797.

27. Molinier J, Ries G, Zipfel C, Hohn B (2006) Transgeneration memory of stress in plants. Nature 442(7106): 1046-1049.

28. Pastor V, Luna E, Mauch-Mani B, Ton J, Flors V (2013) Primed plants do not forget. Environmental and Experimental Botany 94: 46-56.

29. Martínez-Ferri E, Moreno-Ortega G, van den Berg N, Pliego C (2019) Mild water stress-induced priming enhance tolerance to Rosellinia necatrix in susceptible avocado rootstocks. BMC Plant Biology 19(1): 458

30. Samota MK, Sasi M, Awana M, Yada, OP, Amitha Mithra SV, et al. (2017) Elicitor-induced biochemical and molecular manifestations to improve drought tolerance in rice (Oryza sativa L.) through seedpriming. Frontiers in Plant Science 8: 934.

31. Boyko A, Kovalchuk I (2011) Genome instability and epigenetic modification-heritable responses to environmental stress? Current Opinion in Plant Biology 14(3): 260-266.

32. Bräutigam K, Vining KJ, Lafon-Placette C, Fossdal CG, Mirouze M, et al. (2013) Epigenetic regulation of adaptive responses of forest tree species to the environment. Ecology and Evolution 3(2): 399-415.

33. Slaughter A, Daniel X, Flors V, Luna E, Hohn B, et al. (2012) Descendants of primed Arabidopsis plants exhibit resistance to biotic stress. Plant Physiology 158(2): 835-843.

34. Luna E, Toby JAB, Roberts MR, Flors V, Ton J (2012) Next-generation Systemic Acquired Resistance. Plant Physiology 158(2): 844-853.

35. Solla A, Hernández J, Corcobado T, Cubera E (2013) Inducción de resistencia transgeneracional de Quercus ilex ante Phytophthora cinnamomi. En: G. Montero González et al. (eds.) Actas 6 Congreso Forestal Español. Sociedad Española de Ciencias Forestales, Pontevedra, pp.1-12.

36. Kuznicki D, Meller B, Arasimowicz-Jelonek M, Braszewska-Zalewska A Drozda A, et al. (2019) BABA-Induced DNA methylome adjustment to intergenerational defense priming in potato to Phytophthora infestans. Frontiers in Plant Science 10: 650.

37. Ramírez-Carrasco G, Martínez-Aguila K, Alvarez-Venegas R (2017) Transgenerational defense priming for crop protection against plant pathogens: a hypothesis. Frontiers in Plant Science 8: 696. 
This work is licensed under Creative Commons Attribution 4.0 License DOI: 10.19080/JOJHA.2020.01.555599
- Quality Editorial service

- Swift Peer Review

- Reprints availability

- E-prints Service

- Manuscript Podcast for convenient understanding

- Global attainment for your research

- Manuscript accessibility in different formats

( Pdf, E-pub, Full Text, Audio)

- Unceasing customer service

Track the below URL for one-step submission https://juniperpublishers.com/online-submission.php 